\title{
Komodifkasi Agama dalam Polemik Penentuan Awal Bulan Qamariah di Indonesia
}

\author{
Wildani Hefni ${ }^{1}$ \\ Institut Agama Islam Negeri (IAIN) Jember \\ 1email: wildani91@gmail.com
}

\begin{abstract}
This article aims at explaining the ideological political contestation in determining the beginning and end of the qamariah month in Indonesia by using a religious commodification approach. Religious issues that drawn in ideological interest have led to group fanaticis $m$ which makes religion as part of commodification in the construct of pragmatic interests. Two paradigms of Hisab and Rukyat become a symbol of differences in determining the beginning and end of the qamariah month in Indonesia. The ideological and political interpretation was born from this debate. In its history, the ideology of socio-religious organization has become a commodity. Nahdlatul Ulama and Muhammadiyah carried out commodification by carrying different views of the government's decision based on the ir dissatisfaction.
\end{abstract}

\section{Keywords:Religious commodification, $N U$, Muhammadiyah}

\begin{tabular}{l}
\hline \multicolumn{4}{c}{ Abstrak } \\
\hline Artikel ini membahas kontestasi politik ideologis dalam \\
penentuan awal bulan qamariah di Indonesia dengan \\
menggunakan pembacaan komodifikasi agama. Persoalan \\
keagamaan yang ditarik dalam kepentingan ideologis telah \\
mengantarkan pada lapisan fanatisme kelompok yang kerapkali \\
menjadikan agama sebagai komodifikasi dalam konstruk \\
kepentingan pragmatis. Penentuan awal bulan qamariah \\
sejatinya telah diatur namun tetap terjadi perbedaan karena dua \\
pendapat yang mendasarkan pada hisab dan rukyat. Dalam \\
perjalanannya, ideologi organisasi kemasyarakatan dalam Islam \\
telah menjadi komoditas. NU maupun Muhammadiyah \\
melakukan komodifikasi dengan melakukan sebuah pandangan \\
yang berbeda dari pemerintah berlatar ketidakpuasan pada \\
keputusan pemerintah yang menetapkan awal bulan qamariah \\
berdasarkan metode yang berlainan dari mereka.
\end{tabular}

Kata Kunci : Komodifikasi Agama, NU, Muhammadiyah 


\section{A. Pendahuluan}

Penentuan awal bulan qamariah di Indonesia sejatinya telah diatur namun tetap terjadi perbedaan karena adanya dua pendapat yang mendasarkan pada hisab dan rukyat. Tafsir ideologis dan politis lahir dari polemik perdebatan yang tak menemukan ujung pangkalnya.

Polemik perdebatan itu terus berjalan dengan egoisme sektoral menjadi penyebab utamanya. Fanatis me terhadap suatu metode telah melahirkan perbedaan. Dalam aplikasi penentuan awal bulan qamariah, ada yang fanatik terhadap penggunaan sistem hisab. Namun, adapula yang fanatik terhadap penggunaan sistem rukyah. Konsistens $\mathrm{i}$ ini menguatkan masing-masing kelompok untuk berdiri sendiri dan tak mau diajak kompromi dalam proses penyelerasan kriteria dan pemikiran.

$$
\text { Faktanya, dinamika }
$$

perkembangan hisab rukyat di Indonesia akhirnya diwarnai pe mikiran-pemikiran dan pembaruan oleh organisasi masyarakat (ormas) Islam. Pelbagai ormas memiliki metode dan kriteria. Bahkan, dua ormas terbesar di Indonesia yaitu Nahdlatul Ulama (NU) dan Muhammadiyah juga memiliki metode dan kriteria yang berbeda. ${ }^{1}$ Dua paradigma yang dibangun oleh masingmasing ormas ini kemudian menjadi kontestasi yang tak pernah menemukan ujung pangkal. Tidak hanya itu, pelbagai ormas dan aliran keagamaan yang lain, seperti Persis, Thoriqot Naqsabandi, Jamaah Al-Nadzir, Islam Kejawen, dan lainnya. Ketegangan teologis muncul dari penafsiran yang menghasilkan metode dan kritera masing-masing dari berbagai ormas dan aliran keagamaan terkait persoalan hisab rukyat sehingga tak jarang menimbulkan perpecahan. Aliran-aliran tersebut, secara langsung maupun tidak, telah melahirkan perbedaan di kalangan umat Islam Indonesia dalam penentuawan awal bulan qamariah, walaupun tidak mengganggu pada nilainilai substansi keagamaan.

Konflik yang tak berkesudahan ini kemudian menimbulkan peristiwa yang membingungkan dan berimplikasi pada penentuan suatu prosesi ibadah. Tiga peristiwa yang sering terjadi antara lain

1 Wildani Hefni, "Dinamikiyyatu Jam'iyati Nahdlatil Ulama fi Itsbati Awail al-Syuhur al-Qamariah bi Indonesia", Jurnal Al-Ahkam, $28 \quad$ (2) (2018), http://dx.doi.org/10.21580/ahkam.2018.18.2. 2689. 


\section{AL-MARSHAD: JURNAL ASTRONOMI ISLAM DAN ILMU-ILMU BERKAITAN ISSN 2442-5729 (print) || ISSN 2598-2559 (online) \\ http://jurnal.umsu.ac.id/index.php/almarshad \\ DOI: $10.30596 /$ jam.v\% vi\%i.4505 || Vol. 6, No. 1Juni 2020}

sebagai berikut. Pertama, pada saat menentukan akhir bulan sya'ban karena terkait dengan hari pertama bulan berikutnya (bulan puasa). Dalam konteks ini berkaitan dengan penentuan awal dimulainya ibadah puasa. Kedua, pada saat menentukan akhir bulan puasa (Ramadhan). Kaitannya dengan ini, penentuan hari pertama bulan Syawal untuk menentukan kapan dilaksanan ibadah Idul Fitri. Ketiga, pada saat menentukan awal bulan Dzulhijjah karena terkait dengan hari ke sepuluh bulan Dzulhijjah, saat dimana prosesi ibadah Idul Adha dilakukan. ${ }^{2}$

$$
\text { Pelbagai diskusi dan }
$$

pertemuan digelar dalam rangka penyatuan perbedaan ini, namun tak kunjung menemukan titik temu. Kriteria dan paradigma yang telah mengakar di masing-masing ormas menjadi kendala sekaligus landasan keengganan untuk menyatukan persepsi, terlebih ditopang kuat oleh kontestasi ideologis yang sudah lama menunjukkan perbedaan.

$$
\text { Artikel ini membahas }
$$
kontestasi ideologis dari berbagai aliran keagamaan dan ormas yang berjalan

2 Miftahul Ulum, "Fatwa Ulama NU (Nahdlatul Ulama) dan Muhammadiyah Jawa Timur Tentang Hisab Rukyat", Syaikhuna: Jurnal Pendidikan dan Pranata Islam, 10 (2), (2015). dalam tensi konflik dan tak jarang menimbulkan perpecahan akibat tidak seragamnya penentuan awal bulan qamariah di Indonesia. Bagaimana kontestasi itu terus menguat ditopang oleh para tokoh dari masing-masing serta dikuatkan oleh gengsi politik yang selama ini dipegang kuat keduanya. Artikel ini memfokuskan pada aspek penentuan awal bulan qamariah di Indonesia dengan menelusuri pijakan paradigma, relasi tokoh dan kuasa, serta penggiringan diskursus keagamaan pada ruang komodikasi sosial keagamaan dalam tensi politik yang berkepanjangan, terutama dalam dua ormas yaitu Muhammadiyah dan NU.

\section{Diskursus Hisab Rukyah di} Indonesia

Ilmu hisab rukyah yang secara maknawi berarti juga ilmu orbit, pada dasarnya merupakan ilmu Astronomi itu sendiri. Pada zamannya (sebelum dipergunakan teleskop), ilmu astronomi sebagai sebuah observational science yang hanya bisa memperlajari benda-benda langit semata. Benda langit tersebut meliputi matahari, bulan, planet, bintang dan komet. ${ }^{3}$

\footnotetext{
${ }^{3}$ Ahmad Izzuddin, Hisab Rukyah
} Antara Kebenaran Hipotesis dan Verifikasi, 
Ilmu hisab rukyah sangat berkaitan dengan pelaksanaan ibadah umat Islam, seperti penentuan waktu shalat, penentuan arah kiblat, gerhana, dan penentuan awal bulan qamariah. Dengan kata lain, ilmu hisab rukyah ini mempelajari benda-benda langit, yang meliputi fisik benda langit, gerakan benda langit, ukuran benda langit, pos is $\mathrm{i}$ benda langit, serta segal hal yang berkaitan dengan benda-benda langit. ${ }^{4}$ Dalam hal ini, benda langit yang dipe lajari umat Islam adalah matahari, bumi dan bulan. Kesemua itu memiliki keterkaitan erat dengan proses ibadah manusia.

Dalam praktiknya, ilmu hisab modern banyak mempergunakan ilmu pasti yang kebenarannya sudah tidak disangsikan lagi. Ilmu tersebut adalah spherical trigonometri atau ilmu ukur segitiga bola. Disamping itu, ilmu hisab ini mempergunakan data yang dikontrol oleh observasi setiap saat. Atas dasar inilah, banyak kalangan yang mengatakan bahwa ilmu hisab ini

Makalah disampaikan dalam Studium General yang diselenggarakan Fakultas Syariah IAIN Walisongo pada hari Rabu, 29 Februari 2012.

${ }^{4}$ Departemen Agama RI, Almanak Hisab Rukyah, Hisab Rukyah Departemen Agama RI, diterbitkan oleh Proyek Pembinaan Badan Peradilan Agama Islam, tahun 1981, hal 15 memberikan kepastian, namun belum tentu tepat.

Sedangkan rukyah adalah melihat hilal pada saat matahari terbenam tanggal dua puluh sembilan bulan qomariah. Pokok bahasan dalam hisab rukyah adalah penentuan waktu dan posisi benda langit (matahari dan bulan) yang sangat memiliki keterkaitan dengan pelaksanaan ibadah. Dalam konteks ini, penentuan awal bulan qamariah bagi umat Islam merupakan faktor determinan yang sangat fundamental karena berkaitan langsung dengan penentuan hari-hari besar, seperti penentuan awal dan akhir bulan Ramadhan, Syawal dan Dzulhijjah.

\section{Dinamika Penentuan Awal Bulan}

\section{Qamariah dalam Ormas Islam}

Dalam studi ini, penulis memfokukan kajian pada dua ormas besar di Indonesia yaitu NU dan Muhammadiyah. Dalam bagian ini, penulis menggambarkan bagaimana kontestasi polemic perdebatan itu terjadi, dan bagaimana pula dua dinamika dua organisasi ini dalam penentuan awal bulan qamariah selama ini.

Dalam tubuh

Muhammadiyah, ormas ini mulai 


\section{AL-MARSHAD: JURNAL ASTRONOMI ISLAM DAN ILMU-ILMU BERKAITAN ISSN 2442-5729 (print) || ISSN 2598-2559 (online) \\ http://jurnal.umsu.ac.id/index.php/almarshad \\ DOI: $10.30596 / j a m . v \%$ vi\%i.4505 || Vol. 6, No. 1Juni 2020}

menggunakan hisab yang pada awalnya dipelopori oleh KH. Ahmad Dahlan yang merupakan respon terhadap sistem Aboge yang berlaku saat itu. ${ }^{5}$ Ahmad Dahlan bagi kalangan Muhammadiyah dikenal sebagai peletak dasar pemikiran hisab Muhammadiyah. Metode ini digunakan untuk menentukan awal bulan qamariyah dengan sistem ijtima' qablal ghurub, yaitu ketika hari itu terjadi ijtima', maka waktu sesudah terbenamnya matahari adalah awal bulan meskipun hilal tidak wujud pada saat matahari tenggelam.

Dalam penentuan awal bulan qamariah,

Muhammadiyah menggunakan kriteria wujudul hilal. Muhammadiyah memaknai wujudul hilal sebagai penentuan awal bulan qamariah dengan konstruksi jalan tengah antara ijtimak qablal ghurub dan imkan al-rukat. Pada praktiknya, hisab hakiki wujudul hilal adalah kriteria penentuan awal bulan dengan menggunakan prinsip ijtimak (konjungsi) telah terjadi sebelum matahari terbenam (ijtimak qabla alghurub), saat matahari terbenam sudah berada di garis ufuk dengan tanpa

5 H. Rohmat, "Penentuan Awal Bulan Qamariah Menurut Muhammadiyah", Jumal Ijtimaiyya, Vol. 7 No. 1, (2014). melihat derajat ketinggiannya (irtifa'), dan bulan terbenam setelah matahari terbenam, maka pada petang hari tersebut dinyatakan sebagai awal bulan kalender Hijriah. Dengan konsepsi wujudul hilal sebagaimana disebut, Muhammadiyah menganggap bahwa kriteria tersebut lebih memberikan kepastian serta praktis. ${ }^{6}$ Tidak hanya itu, Muhammadiyah dapat mengetahui awal bulan untuk ratusan tahun kedepan dengan menggunakan sistem hisab yang dimaks ud.

Muhammadiyah

berpandangan bahwa jika menggunakan rukyat, maka umat Islam tidak bisa membuat kalender. Rukyat tidak dapat meramal tanggal jauh ke depan karena tanggal baru bisa diketahui pada $\mathrm{H}-1$. Tidak hanya itu, Muhammadiyah memiliki pandangan bahwa rukyat tidak menjadi satu-satunya metode yang dapat menyatukan awal bulan Islam secara global. Hal ini karena rukyat pada visibilitas pertama tidak mengcover seluruh muka bumi. Pada hari yang sama ada muka bumi yang dapat merukyat tetapi ada muka bumi lain yang tidak dapat merukyat.

\footnotetext{
${ }^{6}$ H. Rohmat, "Penentuan Awal Bulan Qamariah Menurut Muhammadiyah", 129.
} 


\section{AL-MARSHAD: JURNAL ASTRONOMI ISLAM DAN ILMU-ILMU BERKAITAN ISSN 2442-5729 (print) || ISSN 2598-2559 (online) \\ http://jurnal.umsu.ac.id/index.php/almarshad \\ DOI: $10.30596 /$ jam.v\%vi\%i.4505 || Vol. 6, No. 1Juni 2020}

Argumen-argumen di atas menunjukkan bahwa rukyat tidak dapat memberikan suatu penandaan waktu yang pasti dan komprehensif. Karena itu, rukyat dianggap tidak dapat menata waktu pelaksanaan ibadah umat Islam secara selaras di seluruh dunia. ${ }^{7}$

Dalam tataran teoritis, Muhammadiyah memang meletakkan hisab dan rukyat secara sejajar. Hanya saja dalam wilayah praksis, Muhammadiyah memandang bahwa hisab sudah cukup mewakili sehingga rukyat jarang sekali dipraktekkan. Dalam pandangan Muhammadiyah penentuan awal bulan hijriyah masuk ke domain aktivitas ta'aquliy, sehingga otomatis rukyah bukanlah ibadah.

Adapun di tubuh ormas NU, ormas ini dalam penentuan awal bulan qamariah di Indonesia, melakukan empat tahapan. Pertama, tahap penyerasian hisab awal bulan, kedua, tahap penyelenggaraan rukyatul hilal bil fi'li, ketiga, tahapan mengikuti sidang itsbat dengan pemerintah dan keempat, mengeluarkan ikhbar (informasi)

${ }^{7}$ Syamsul Anwar, Hari Raya \& Problematika Hisab-Rukyat (Yogyakarta: Suara Muhammadiyah, 2008), h. 5. kepada seluruh masyarakat Indonesia, khususnya kalangan nahdliyyin.

Bagi ormas NU, kedudukan hisab hanya sebagai pembantu dalam pelaksanaan rukyatul al-hilal di lapangan. Oleh karena itu, NU walaupun sudah mempunyai prediksi, namun tidak berani menetapkan awal bulan Ramadhan, Syawal dan dzulhijah dengah hisab, namun tetap menunggu hasil rukyat. Penetapan ini diambil berdasarkan alasan-alasan syar'i yang dipandang kuat untuk dijadikan pedoman peribadatan yang dapat dipertanggungjawabkan dan diambil dalam keputusan Bahtsul Masail NU. ${ }^{9}$ Kehati-hatian ini dibangun dalam konstruk metodologi NU yang berkeyakinan bahwa penentuan awal bulan qamariah harus didasarkan pada penglihatan secara langsung (rukyat bil ain).

Sikap NU tentang sistem penentuan awal bulan Qamariyah, khususnya awal bulan Ramadlan,

${ }^{8}$ Ghazali Masioeri, Pedoman Hisab
dan Rukyat Nahdlatul Ulama (Lajnah
Falakiyah Pengurus Besar Nahdlatu Ulama,
Jakarta, 2006), h. 14.
9 Pranada Boy Zulian, An Analysis
of Dominant Legal Ideas and Mode of
Thought of Fatwa Making Agencies and
Their Implications in The Post-New Order
Period in Fatwa in Indonesia (Amsterdam:
Amsterdam University Press, 2018), h. 24.




\section{AL-MARSHAD: JURNAL ASTRONOMI ISLAM DAN ILMU-ILMU BERKAITAN ISSN 2442-5729 (print) || ISSN 2598-2559 (online) \\ http://jurnal.umsu.ac.id/index.php/almarshad \\ DOI: $10.30596 /$ jam.v\%vi\%i.4505 || Vol. 6, No. 1Juni 2020}

Syawal, dan Dzulhijjah diambil me lalui keputusan Muktamar NU XXVII di Situbondo (1984), Munas Alim Ulama di Cilacap (1987), Seminar Lajnah Falakiyah NU di Pelabuhan Ratu Sukabumi (1992), Seminar Penyerasian Metode Hisab dan Rukyat di Jakarta (1993), dan Rapat Pleno VI PBNU di Jakarta (1993), yang akhirnya dituangkan dalam Keputusan PBNU No. 311/A.II.04.d/1994 tertanggal 1 Sya'ban 1414 H/13 Januari 1994 M, dan Muktamar NU XXX di Lirboyo Kediri (1999). ${ }^{10}$

Di kalangan NU, kata hilal (new moon) yang terdapat da lam QS. alBaqarah [2]: 189 dianggap paling tegas dan kuat sebagai landasan beristinbath. Dengan kata lain, rukyat merupakan landasan utama bagi NU dalam menetapkan awal dan akhir bulan qamariah.

Dari metode hisab yang berkembang tersebut, hitungan hisab awal bulan yang merupakan hasil dari metode hisab penyerasian yang

${ }^{10}$ Ahmad Zahro, Lajnah Bahtsul Masail Ulama 1926-1999, Telaah Kritis Terhadap Keputusan Hukum Fiqih. Disertasi Program Doktor UIN Sunan Kalijaga Yogyakarta, 2001. Lihat pula Malik Madaniy, "Penentuan Awal Bulan Qamariah Sepanjang Ketentuan Syara". Jurnal Asy-Syir'ah, Vol. 37, No. 2, (2001). dilakukan oleh NU kemudian diterbitkan dalam bentuk almanak. Selanjutnya digunakan sebagai pendukung dan pemandu rukyat. Sedangkan rukyat digunakan sebagai hasil koreksi dari hisab yang telah dibuat. Maka, dalam konteks kehatihatian sekaligus sebagai koreks $\mathrm{i}$ validitas, dalam setiap awal bulan qamariah yang dicantumkan dalam almanak NU selalu diberi catatan "menunggu hasil rukyat al-hilal bil fi'li'. Wacana ini kemudian menjadi menarik karena NU berusaha untuk mengikuti perkembangan pengetahuan dengan menggunakan metode hisab, namun tetap menjaga autentisitas paradigma yang telah dipegang yaitu penggunaan kriteria rukyat sebagai hasil final.

Dalam prakteknya, kriteria imkan al-rukyat secara empirik mempunyai indikator minimal tingg $\mathrm{i}$ hilal 2 derajat, umur bulan 8 jam, dan jarak antara matahari dan bulan 3 derajat. Dalam konteks ini, apabila secara ilmiah terdapat perkembangan standar ukuran kriteria imkan al-rukyat, maka bagi NU dianggap tidak ada masalah karena yang menjadi dasar bukan kriteria imkan al-rukyat tetapi 


\section{AL-MARSHAD: JURNAL ASTRONOMI ISLAM DAN ILMU-ILMU BERKAITAN ISSN 2442-5729 (print) || ISSN 2598-2559 (online) \\ http://jurnal.umsu.ac.id/index.php/almarshad \\ DOI: $10.30596 /$ jam.v\%vi\%i.4505 || Vol. 6, No. 1Juni 2020}

hasil rukyat atau dzhuhurul hilal

dan berkelanjutan yang akhirnya (nampaknya hilal).

menghasilkan $\quad z i j-z i j \quad$ (tabel-tabel

Rukyat yang dianut NU astronomis) yang terkenal dan hingga didasarkan atas hasil dari kini masih menjadi rujukan, seperti Zij penyelenggaraan rukyatul hilal bil fi'li dalam ne geri dan berlaku satu wilayah hukum (wilayatul hukmi). Hal ini berbeda dengan keputusan Saudi Arabia. Dengan kata lain, rukyat yang dianut oleh NU adalah rukyat nasional dalam bingkai NKRI. NU menyelenggarakan rukyat dengan memakai alat-alat tradisional sampai alat modern. NU juga mempunyai NUMO yaitu Nahdlatul Ulama Mobile Observatory, sebuah observatorium keliling yang mudah digerakkan kemana saja untuk melakukan observasi (Masroeri, 2006: 5).

NU hingga kini tetap menggunakan metode rukyat dan tidak ada pergeseran pradigma mengenai metode yang telah diyakini sejak dulu. NU hanya mengubah kriteria yang dipatok. Hal ini semakin kuat ketika melihat kelebihan metode rukyat. Kelebihan metode rukyat adalah akurasi yang ilmiah. Hal ini terbukti dengan perkembangan ilmu falak pada zaman keemasan Islam. Para ahli terdahulu melakukan pengamatan secara serius al-Jadid karya Ibnu Shatir (1306 M/706 H), dan Zij Jadid Sultani karya Ulugh $\operatorname{Beg}\left(1394-1449\right.$ M/797-853 H). ${ }^{11}$

Dalam prakteknya, penetapan awal bulan qamariah seperti awal Ramadhan, Syawal dan dzhulhijjah di Indonesia adalah penetapan atau sidang itsbat pemerintah yang dalam hal ini dilakukan oleh Kementrian Agama RI. Pemerintah dalam menetapkan awal bulan qamariah juga mengikuti atas dasar laporan hasil rukyat dan juga hasil hisab. Laporan rukyat ini erat kaitannya dengan metode yang dipakai oleh kalangan NU. Dengan kata lain, peran NU dalam penetapan awal bulan qamariah sangat besar dan menjadi bahan masukan dan rujukan pemerintah dalam menetapkan awal bulan qamariah tersebut.

Dalam kasus-kasus yang berbeda atau berhari raya tidak serempak antara NU dan pemerintah, bisa dimungkinkan Kementerian Agama

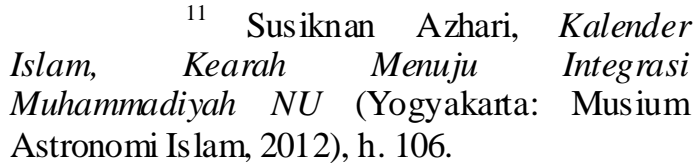




\section{AL-MARSHAD: JURNAL ASTRONOMI ISLAM DAN ILMU-ILMU BERKAITAN ISSN 2442-5729 (print) || ISSN 2598-2559 (online) \\ http://jurnal.umsu.ac.id/index.php/almarshad \\ DOI: $10.30596 / j a m . v \%$ vi\%i.4505 || Vol. 6, No. 1Juni 2020}

RI memutuskan dalam sidang itsbat untuk menolak atas hasil rukyat dan menggunakan hasil hisab. Pada posis i seperti ini, hasil rukyat yang dilakukan oleh masyarakat NU menjadi wewenang NU untuk menginformasikan atau menyebakan informasi berdasarkan analis is NU kepada segenap warga nahdliyin di seluruh Indonesia. ${ }^{12}$

NU mengikuti sidang itsbat dan memberikan informasi dan pendapat atas hasil yang diperoleh dari laporan hasil rukyat di seluruh Indonesia. Mulai tahun 1984, kalangan NU telah banyak berkontribusi dalam perkembangan hisab rukyat di Indonesia dengan turut andil bersama pemerintah dalam menetapkan sidang itsbat awal bulan qamariah. Hingga kini, NU juga tetap berkontribusi dengan menyampaikan hasil laporan rukyat karena NU menggunakan metode rukyat bil fi'li. Setelah mengikuti sidang itsbat (penetapan) dengan pemerintah, kemudian PBNU mengeluarkan ikhbar (informasi). Ikhbar PBNU ini berfungs i sebagai berikut. Pertama, menyampaikan pendirian NU tentang awal Ramadhan, awal Syawal, awal

\footnotetext{
${ }^{12}$ Ghazali Masmeri, Pedoman Hisab dan Rukyat Nahdlatul Ulama”, h. 13.
}

Dzhulhijjah. Kedua, memperkuat penetapan yang dilakukan Menteri Agama jika diterbitkan berdasarkan rukyat. Ketiga, koreksi terhadap penetapan Menteri Agama ketika diputuskan de ngan mengabaikan rukyat. Koreksi ini dapat dipahami sebagai pembuktian argumentasi terhadap metode yang digunakan NU. Dalam hal ini, jika penetapan Menteri Agama mengabaikan rukyat, maka kedudukan ikhbar PBNU mempunyai nilai itsbat yaitu dapat berlaku umum bagi umat Islam di Indonesia. Namun, ikhbar yang diberikan oleh NU hanya sebatas informasi yang tidak mengandung paksaan untuk mengikuti, melainkan sebagai informasi resmi hasil NU yang sejatinya diberikan pada kalangan nahdliyyin. Terlepas apakah umat Islam akan mengikuti atau tidak, hal itu tidak menjadi persoalan karena yang memiliki otoritas penentuan adalah pemerintah dalam hal ini Kementerian Agama.

Dalam perjalanan hisab rukyat di Indonesia, khususnya dalam penetapan awal bulan qamariah, NU mengalami perjalanan panjang dan penuh dinamika. Bahkan, terlibat konflik yang tak berkesudahan antara 
pengikut organisasi NU dan organisasi kemasyarakatan lainnya seperti Muhammadiyah. Bahkan, NU dengan pemerintah juga pernah berbeda dalam menetapkan awal bulan qamariah. Dalam beberapa kasus, bulan yang masih dibawah ufuk menurut perhitungan astronomi dilaporkan terlihat dan diambil sebagai dasar penetapan awal bulan, hal ini terjadi pada penetapan Idul Fitri tahun 1413 H/1993 M. Namun sejak tahun 1994, PBNU telah membuat pedoman bahwa kesaksian hilal bisa ditolak bila semua ahli hisab sepakat menyatakan hilal tidak mungkin dirukyat. Secara lebih tegas dinyatakan bahwa kesaksian rukyatul hilal bisa ditolak bila tidak didukung ilmu pengetahuan atau hisab yang akurat. Dalam konteks ini, progresifitas pandangan NU dapat dibaca dengan tidak mengabaikan ilmu pengetahuan dan teknologi yang berkembang.

Contoh kasus yang pernah terjadi adalah penolakan pada penentuan Idul Fitri tahun 1418 H/1998 $\mathrm{M}$ dalam sidang itsbat pemerintah yang menolak kesaksian Cakung dan Bawean. Saat itu hilal masih di bawah kriteria imkan al-rukyat 2 derajat.
Namun prinsip itu belum secara konsisten berjalan dilakukan karena PWNU justru menerima kesaksian tersebut. Namun, dalam perjalanannya, NU telah berijtihad menerima batasan imkanur al-rukyat (kemungkinan rukyat) dua derajat walaupun sosialisasinya masih kurang ke semua jajaran di bawah. Proses ini secara berkesinambungan menuju kepada yang lebih baik karena berkaca pada kasus Idul Fitri pada tahun 1993 yang menerima kesaksian rukyatul hilal padahal bulan sudah di bawah ufuk menurut hisab astronomi yang akurat. ${ }^{13}$

\section{B. Me tode Penelitian}

Penelitian ini termasuk dalam penelitian kepustakaan (library research) ${ }^{14}$, yaitu penulis berbicara banyak dengan bukubuku, arsip-arsip, dokumen-dokumen, dan catatan-catatan.Jenis penelitian ini

${ }^{13}$ M Nawawi, Menegakkan Madzhab Negara, dalam Hisab Rukyah dan Perbedaannya (Jakarta: Peningkatan Pengkajian Kerukunan Umat Beragama, Puslitbang Kehidupan Beragama, Badan Litbang Agama dan Diklat Keagamaan Departemen Agama RI, 2004), h. 218.

${ }^{14}$ Bungaran Antonius Simanjuntak dan Soedjito Sosrodihardjo, Metode Penelitian Sosial, (Jakarta: Yayasan Pustaka Obor Indonesia, 2009), h. 8. 
adalah kualitatif dengan pendekatan deskriptif analitik. ${ }^{15}$

\section{Hasil Dan Pembahasan}

\section{Wacana Komodifikasi Agama:}

\section{Sebuah Diskursus}

Komodifikasi

agama

menitikberatkan pada transformasi pesan media pada ranah pemasaran ekonomi. Dengan kata lain, komodifikasi dimaksudkan sebagai proses transformasi barang yang semula nilai gunanya tidak seberapa, kemudian dialihfungsikan menjadi bernilai dan masuk dalam pertimbangan ekonomi. Dalam analisis Fealy, komodifikasi agama terlihat dalam ekspresi keimanan melalui berbagai komoditas yang berlabel Islam. ${ }^{16}$

Dalam komodifikasi agama, ciri komersial sangat nampak. Dalam konstruk komunikasi agama, simbolsimbol yang melekat dalam ajaran keagamaan, dapat dijadikan sebagai sebuah komoditas yang dipertukarkan, diperebutkan, dikontestasikan, diperdebatkan, dan ditentukan oleh daya

${ }^{15}$ Jusuf Soewadji, Pengantar Metodologi Penelitian, (Jakarta: Mitra Wacana Media, 2012), h.34.

${ }^{16}$ Greg Fealy dan Sally White (ed), Expressing Islam: Religious Life and Politics in Indonesia (Singapura: ISEAS, 2008). takar keuntungan. ${ }^{17}$ Dalam salah satu varian Marxisme, ideologi tergantung pada kekuatan ekonomi. Dalam pandangan teori ini, untuk memperjuangkan politik melalui institusi apapun, semisal organisasi kemasyarakatan, sekolah, madrasah, pesantren, pariwisata, harus dikaitkan dengan ekonomi guna memperoleh nila i tukar dari komersialisasi ideologi tersebut.

Teori ekonomi politik bercirikan tiga hal. Pertama, komodifikasi yaitu proses mengubah nilai guna menjadi nilai tukar. Lembaga atau institusi sering dijadikan komodifikasi dan berubah menjadi lembaga ekonomi. Ketika menjual informasi atau ilmu pengetahuan, mereka yang mempunyai hidden interest (agenda tersembunyi) melakukan dalam rangka menopang kepentingan ideologis yang diusung. Kedua, spasialisasi yaitu proses mengatasi hambatan ruang dan waktu dalam kehidupan sosial. Ruang dan waktu dijadikan sarana guna mendapatkan uang dan keuntungan.

${ }^{17}$ Peter Berger, The Sacred Canopy: Elements of a Sociological Theory of Religion (New York: Doubleday and Company, 1969). 
Keduanya merupakan perpanjangan organisasional dari kelompok yang memiliki kekuasaan. Keduanya dipakai untuk mengerucutkan waktu yang dibutuhkan guna memindahkan barang, manusia dan pesan dalam rangka menopang kinerja kelompok pemilik kekuasaan. Hal ini akan menciptakan jaringan kerja (networking).

Sedangkan ketiga adalah strukturisasi yaitu penciptaan hubungan antar-agen dalam sebuah tatanan sosial yang ditandai dengan adanya unsur power atau kekuatan. Dalam strukturisasi ada pembedaan antara struktur atas (supra structure) dan struktur bawah (structure base). Antara kedua struktur ini dan aktor bersifat saling memengaruhi, bahkan bisa terjadi pertarungan kekuasaan (struggle of power). ${ }^{18}$

\section{Komodifikasi Agama dalam}

Polemik Penetuan Awal Bulan

\section{Qamariah}

Diskursus penentuan awal bulan qamariah di Indonesia banyak yang terfokus pada kontestasi dua ormas besar yaitu NU dan

18 Vincent Mosco, The Political Economy of Communicataion (London: Sage Publication, London, 1996), h. 134.
Muhammadiyah. Hal ini menarik karena dua ormas ini menjadi titik pangkal polemik perdebatan. Sejauh ini, kajian yang membahas tentang faktor kemungkinan terjadinya nilai tukar ekonomi-politik, dalam hal ini komodifikasi agama dalam penentuan awal bulan qamariah di Indonesia, belum banyak yang membahasnya.

Sejatinya ormas NU dan Muhammadiyah sama-sama mengakui eksistensi hisab dan rukyat. Bagi dua ormas ini, masing-masing metode menemukan tempatnya dengan porsi yang cukup signifikan dan kemudian menjadi pijakan masing-masing. Bagi NU, sudah jelas rukyat menjadi pijakan dengan berdasar kepada penampakan hilal. Sedangkan bagi Muhammadiyah, hisab menjadi pijakan utama seiring dengan perkembangan ilmu pengetahuan dan teknologi dan memperhatikan eksistensi hilal. Permasalahan yang selalu muncul, kedua ormas tetap bertahan terhadap kriteria dan paradigma yang telah dibangun sejak lama. Implikasiknya, keengganan untuk memadukan dua kriteria (hisab dan rukyat) mengantarkan pada faksi teologis dan terjebak pada fanatisme kelompok yang 
dibangun atas kepentingan ideologis pragmatis.

$$
\text { Kontestasi kepentingan }
$$
ideologis-politis dapat dibaca dari aspek relasi-kuasa pemerintah di jajaran Kementerian Agama sejak kisaran tahun 1960. Adagium posisi Menteri Agama akan menentukan proses penentuan awal bulan qamariah di Indonesia menjadi titik pijak untuk menganalisis lebih jauh. Dari sisi ideologis, jika Menteri Agama berasal dari kalangan NU, maka penentuan awal bulan qamariah di Indonesia akan lebih condong menggunakan kriteria dan paradigma rukyat. Sebaliknya, jika Menteri Agama berasal dari kalangan Muhammadiyah, maka proses penentuan awal bulan qamariah di Indonesia lebih berpihak pada penggunaan sistem hisab. Tesis ini belum tentu benar, namun setidaknya itu dapat dibaca dalam kontestasi politik-ideologis dengan telaah komodifikasi agama dalam penentuan awal bulan qamariah di Indonesia.

Sejak 2003, perbedaan yang mencolok dan konflik berkepanjangan antara ormas yang satu dengan yang lainnya atau dengan pemerintah dalam menentukan awal bulan qamariah kian meredup. Relasi NU dengan pemerintah berjalan dengan baik. Relasi ini menguat dan menjadi sentral dalam perdebatan penentuan awal bulan qamariah di Indonesia karena ada ada adagium yang mengatakan bahwa jika Menteri Agamanya berasal dari kalangan NU, maka penentuan awal bulan qamariah menggunakan rukyat. Namun, jika Menteri Agamanya berasal dari Muhammadiyah, maka penentuan awal bulan qamariah menggunakan sistem hisab.

Namun, faktor tersebut tidak menjadi masalah yang berkelanjutan dalam penentuan awal bulan qamariah. Hal ini terbukti pada saat Presiden RI dijabat oleh Abdurrahman Wahid dan Menteri Agama pada saat dijabat oleh Saiq Aqil Munawar. Begitu juga pada saat dijabat oleh Tolhah Hasan dan Maftuh Basyuni hingga Suryadarma Ali saat ini. ${ }^{19}$

Dari realitas tersebut, varian ekonomi-politik dari Marxisme terlihat dari proses NU maupun Muhammadiyah melakukan komodifikasi dengan melakukan sebuah

19 Wildani Hefni, "Ideological Political Contestation in the Discourse of Hisab Rukyat in Indonesia", Jurnal Penelitian, Vol. 16, No. 1, 2019), h. 88. 


\section{AL-MARSHAD: JURNAL ASTRONOMI ISLAM DAN ILMU-ILMU BERKAITAN ISSN 2442-5729 (print) || ISSN 2598-2559 (online) \\ http://jurnal.umsu.ac.id/index.php/almarshad \\ DOI: $10.30596 /$ jam.v\% vi\%i.4505 || Vol. 6, No. 1Juni 2020}

pandangan yang berbeda dari pemerintah yang berlatar ketidakpuasan dengan keputusan pemerintah melalui Menteri Agama yang menetapkan awal bulan qamariah berdasarkan metode yang berlainan dari keyakinan yang digunakan.

NU dan Muhammadiyah juga melakukan strukturisasi yaitu penciptaan hubungan dengan pemerintah dalam rangka menopang masa umat Islam kedepan agar tidak terjadi perpecahan dalam proses penentuan awal bulan qamariah. Pada tahun 1999, saat Menteri Agama RI dijabat oleh Tolhah Hasan, bias politik ini kian redup. Yang terjadi hampir didominasi kepada faktor pemahaman dan faktor keagamaan serta doktrin.

Telah menjadi rahasia publik bahwa antara Muhammadiyah dan NU pada kisaran tahun 1970 hing ga 1990an, terlibat dalam persaingan merebut dominasi jabatan elite di lingkungan Departemen Agama RI (sebelum berubah nama menjadi Kementerian Agama). Pada awal orde baru, NU dapat mempertahankan dominasinya di Depag. Tetapi begitu jabatan tertinggi di lingkungan Kemenag dipegang Mukti

Ali, praktis dominasi tersebut bergeser kegolongan modernis. ${ }^{20}$

Pada masa orde baru kecenderungan ini sangat terasa saat Menteri Agama dipimpin oleh Munawir Syadzali. Sejak era Mukti Ali hingga Munawir Syadzali, keputusan tentang penetapan awal bulan qamariah pada zaman Munaw ir Syadzali lebih condong pada penggunaan metode hisab. Sementara dalam kurun waktu tahun 1946 sampai tahun 1970, pemerintah Indonesia dalam menetapkan awal bulan qamariah menggunakan rukyat dan menjadikan hisab sebagai sarana penunjang.

Perselisihan politik menjadi pemantik lahirnya pelbagai faksi yang melahirkan interpretasi dan pemahaman yang berbeda. Lambat laun, pemikiranpemikiran terus bermunculan dengan paham dan ajaran yang berbeda-beda dan terpetakan. Dengan kata lain, dalam perjalanannya, ideologi organisasi kemasyarakatan dalam Islam telah

20 Ali Munhanif, Prof. Dr. Mukti Ali: Modernisasi Politik-Keagamaan Orde Baru dalam Menteri-Menteri Agama RI: Biografi Sosial-Politik (Jakarta: Indonesian Netherlands Cooperation in Is lamic Studies (INIS) dan Pusat Pengkajian Is lam dan Masyarakat (PPIM) serta Badan Litbang Agama Departemen Agama RI, 1998), h. 270. 


\section{AL-MARSHAD: JURNAL ASTRONOMI ISLAM DAN ILMU-ILMU BERKAITAN ISSN 2442-5729 (print) || ISSN 2598-2559 (online) \\ http://jurnal.umsu.ac.id/index.php/almarshad \\ DOI: $10.30596 / j a m . v \%$ vi\%i.4505 || Vol. 6, No. 1Juni 2020}

menjadi komoditas, termasuk dalam penentuan awal bulan qamariah.

Sejalan dengan semakin berkembangnya ideologi dan pemahaman masing-masing dari organisasi-organisasi kemasyarakatan, pengajaran dan pemahaman tentang Islam merambah ke arah yang lebih komersial. Dalam konteks perkembangan tersebut, interaksi antara mazhab (ideologis) dan lembaga pemerintahan juga lebih komersial dan sering bersifat saling melengkapi (political interest). Pada satu sisi, wujud kompromi dapat dibangun, tapi pada sisi lain, rivalitas menjadi cara untuk menunjukkan eks istensi. Dalam konteks rivalitas, persaingan dinamis (dynamic competition) hadir untuk berkuasa dengan membuat strategi untuk memperebutkan opini publik.

Perseteruan NU dan Muhammadiyah erat kaitannya dengan kepentingan politik sehingga posis $\mathrm{i}$ Menteri A gama juga sangat menentukan terhadap proses penetapan awal bulan qamariah. Di sisi lain, watak komersialisasi untuk menyebarkan ajaran dan doktrin semakin banyak digunakan oleh kelompok yang memiliki perjuangan politik yang biasanya berhadapan dengan lawan mainstream yang ada, misalnya kelompok sosialis melawan kelompok kapitalis.

Dalam tubuh NU, pada tahun $1412 \mathrm{H}$, NU menetapkan Idul fitri berbeda dengan keputusan pemerintah. Sikap NU yang berbeda dengan keputusan pemerintah ini menunjukkan bahwa NU tidak konsisten de ngan hasil keputusan Munas Alim Ulama NU di Sukerojo Situbondo pada tanggal 6 Rabiul Awal 1404 H/21 Desember 1983 M yang menyatakan bahwa keputusan pemerintah jika berdasar pada hisab maka tidak wajib diikuti. Namun, NU justru tidak menerima keputusan pemerintah pada penetapan awal Syawal tahun $1412 \mathrm{H}$ yang berdasar pada istikmal (penyempurnaan tiga puluh hari). Sedangkan pada tahun 1423 $\mathrm{H}$, NU dapat menerima istikmal sebagai landasan untuk memulai Idul Fitri pada tahuan $1423 \mathrm{H}$.

Dua kasus ini memberikan indikasi bahwa perbedaan dan perdebatan seputar hisab rukyat tidak semata-mata persoalan akademik-ilmiah namun juga merambah kepada persoalan politik dan ekonomi, dalam hal ini komodifikasi agama. 
Hal ini terja di pada masa orde baru dan awal reformasi. Kenyataan ini diperkuat oleh data Direktorat Pembinaan Peradilan Agama Depertemen Agama RI yang menyebutkan bahwa ketinggian hilal yang menyebabkan perbedaan awal Ramadhan, Syawal, dan dzhulhijjah hampir sama. Namun dalam prakteknya dapat berlainan.

\section{Kesimpulan}

Perselisihan politik menjadi pemantik lahirnya pelbagai faksi yang melahirkan interpretasi dan pemahaman yang berbeda dalam penentuan awal bulan qamariah. Lambat laun, pemikiran-pemikiran terus bermunculan dengan paham dan ajaran yang berbedabeda dan terpetakan. Dengan kata lain,

\section{Daftar Pustaka}

Anwar, Syamsul. 2008. Hari Raya \& Problematika Hisab-Rukyat. Yogyakarta: Suara Muha mmadiyah.

Azhari, Susiknan. 2012. Kalender Islam, Kearah Mепији Integrasi Muhammadiyah NU. Yogyakarta: Musium Astronomi Is lam. dalam perjalanannya, ideologi organisasi kemasyarakatan dalam Is lam telah menjadi komoditas, termasuk dalam penentuan awal bulan qamariah.

NU maupun Muhammadiyah melakukan komodifikasi dengan melakukan sebuah pandangan yang berbeda dari pemerintah yang berlatar ketidakpuasan dengan keputusan pemerintah melalui Menteri Agama yang menetapkan awal bulan qamariah berdasarkan metode yang berlainan dari keyakinan yang digunakan. NU dan Muhammadiyah juga melakukan strukturisasi yaitu penciptaan hubungan dengan pemerintah dalam rangka menopang masa umat Islam kedepan agar tidak terjadi perpecahan dalam proses penentuan awal bulan qamariah.

Fealy, Greg, 2008. Expressing Islam: Religious Life and Politics in Indonesia. Singapura: ISEAS.

Hefni, Wildani. 2018. Dinamikiyyatu Jam'iyati Nahdlatil Ulama fi Itsbati Awail al-Syuhur alQamariah bi Indonesia. AlAhkam, 28 http://dx.doi.org/10.21580/ahk am.2018.18.2.2689. 
Hefni, Wildani, 2019. "Ideological

Political Contestation in the

Discourse of Hisab Rukyat in Indonesia", Jurnal Penelitian, Vol. 16, No. 1.

Izzuddin, Ahmad. 2007. Fiqh Hisab Rukyah, Menyatukan NU dan Muhammadiyah dalam Penentuan Awal Ramadhan, Idul Fitri, dan Idul Adha. Jakarta: Erlangga.

Izzuddin, Ahmad. 2012. Hisab Rukyah Antara Kebenaran Hipotesis dan Verifikasi, Makalah disampaikan dalam Studium General yang diselenggarakan Fakultas Syariah IAIN Walisongo pada hari Rabu, 29 Februari 2012.

Madaniy, Malik. 2003. Penentuan Awal Bulan Qamariah Sepanjang Ketentuan Syara. Asy-Syir'ah, 37 (2).

Masroeri, Ghazali. 2006. Pedoman Hisab dan Rukyat Nahdlatul Ulama. Lajnah Falakiyah Pengurus Besar Nahdlatu Ulama, Jakarta.

Munhanif, Ali. Mukti Ali. 1998. Modernisasi PolitikKeagamaan Orde Baru dalam Menteri-Menteri Agama RI: Biografi Sosial-Politik. Azra. Jakarta: Indonesian
Netherlands Cooperation in Islamic Studies (INIS) dan Pusat Pengkajian Islam dan Masyarakat (PPIM) serta Badan Litbang Agama Departemen Agama RI.

Mosco, Vincent. 1996. The Political Economy of Communicataion, London: Sage Publication, London.

Nawawi, M. 2004. (Menegakkan Madzhab Negara, dalam Hisab Rukyah dan Perbedaannya. Jakarta: Peningkatan Pengkajian Kerukunan Umat Beragama, Puslitbang Kehidupan Beragama, Badan Litbang Agama dan Diklat Keagamaan Departemen Agama RI.

Rohmat, H. 2014. Penentuan Awal Bulan Qamariah Menurut Muha mmadiyah. Ijtimaiyya, 7 (1).

Ulum, Miftahul. 2015. Fatwa Ulama NU (Nahdlatul Ulama) dan Muhammadiyah Jawa Timur Tentang Hisab Rukyat. Syaikhuna: Jurnal Pendidikan dan Pranata Islam, 10 (2).

Zulian, Pradana Boy. 2018. An Analys is of Dominant Legal Ideas and Mode of Thought of Fatwa Making Agencies and 
Their Implications in The

Post-New Order Period in

Fatwa in Indonesia.

Amsterdam University Press.

https ://www.jstor.org/stable/j.

ctv157bk2.9.

Zahro, Ahmad. 2001. Lajnah Bahtsul

Masail Ulama 1926-1999,

Telaah Kritis Terhadap

Keputusan Hukum Fiqih.

Disertasi Program Doktor UIN

Sunan Kalijaga Yogyakarta,. 